\title{
Pelatihan penggunaan podcast dan audiobook untuk meningkatkan kemampuan berbicara peserta kursus di LKP-MEC Namlea
}

\author{
Abd. Rahman ${ }^{1}$, Azwan $^{2}$ \\ ${ }^{1}$ Pendidikan Bahasa Inggris, FKIP Universitas Iqra Buru, Maluku \\ ${ }^{2}$ Sastra Inggris, Fakultas Sastra Universitas Iqra Buru, Maluku \\ Email Korespondensi: rahmanabd716@gmail.com
}

Received May 18, 2021; Revised June 28, 2021; Accepted July 5, 2021

\begin{abstract}
Abstrak
Keterampilan berbicara merupakan keterampilan yang sangat vital bagi peserta kursus di LKP MEC untuk memenuhi kebutuhan mereka dalam menghadapi dunia kerja. Pelatihan penggunaan podcast dan audiobook untuk meningkatkan kemampuan berbicara berlangsung selama 16 kali pertemuan. Dalam proses pelatihan, pertama-tama para peserta dibimbing mengenai tata cara dalam mengakses dan menggunakan podcast atau audiobook melalui media proyektor yang bertujuan untuk memberikan pengetahuan tentang penggunaan media teknologi informasi dan komunikasi untuk meningkatkan kemampuan berbicara. Lebih lanjut podcast dan audiobook juga dapat diakses melalui perangkat/handphone setiap peserta pelatihan sehingga mereka dapat mendengarkan percakapan Bahasa Inggris secara mandiri. Materi percakapan pada podcast dan audiobook merupakan materi otentik yang membantu para peserta dalam memperoleh pengetahuan bahasa, karena setiap percakapan atau dialog diucapkan oleh penutur Bahasa Inggris. Untuk mengasah kemampuan berbicara dalam proses pelatihan, setiap peserta meniru cara berbicara, aksen, dialek, dan pengucapan pembicara, disamping itu, mereka mencatat kosakata dan kalimat, dan berlatih berbicara secara berpasangan dengan menggunakan setiap pengetahuan bahasa yang mereka peroleh secara konsisten. Sebanyak 15 orang atau $75 \%$ dari jumlah peserta yang telah mengikuti pelatihan dinyatakan kompeten dalam penguasaan kemampuan berbicara dan mampu berdialog menggunakan ragam bahasa Inggris lisan dengan baik dan benar hingga akhirnya diterima untuk magang di hotel Grand Sarah Namlea.
\end{abstract}

Kata Kunci: pelatihan; podcast; audiobook; kemampuan berbicara

Speaking skills are vital skills for the LKP MEC course participants to meet their needs in facing the world of the job. The training on using podcasts and audiobooks to improve speaking skills took place for eight meetings. In the training process, the participants were first guided on the procedures for accessing and using podcasts or audiobooks through projector media to provide knowledge about information and communication technology to improve speaking skills. Furthermore, podcasts and audiobooks can also be accessed through each trainee's device/mobile phone so that they can listen to English conversations independently. Conversational materials on podcasts and audiobooks included in authentic materials that help participants gain knowledge of the language. To hone speaking skills in the training process, each participant imitates the speaker's way of speaking, accent, dialect, and pronunciation. In addition, they record vocabulary and sentences and practice speaking in pairs using each language knowledge they acquire consistently. As many as 15 people or 75 per cent of the participants who had attended the training were declared competent in mastering speaking skills and fluency in having dialogue using a variety of spoken English properly and correctly until they were finally accepted for an internship at the Grand Sarah Hotel of Namlea.

Keywords : training, podcast, audiobook, speaking ability.

\section{PENDAHULUAN}

Lembaga Kursus dan Pelatihan Master English Course merupakan salah satu lembaga pendidikan nonformal yang berfokus pada pengajaran keterampilan berbahasa inggris untuk memenuhi kebutuhan masyarakat, dunia usaha maupun dunia industri. Tujuan utama dari LKP MEC adalah untuk membekali dan memberikan pengetahuan, keterampilan, kecakapan berbahasa inggris lisan maupun tertulis kepada setiap peserta agar mampu mengembangkan diri, profesi, berusaha secara mandiri, dan/atau melanjutkan pendidikan 
ke jenjang yang lebih tinggi[1]. Namun, minimmya penguasaan kemampuan berbicara merupakan masalah besar yang dialami oleh setiap peserta kursus di LKP MEC. Tercatat, sebanyak $80 \%$ dari total peserta kursus dan pelatihan Bahasa Inggris di LKP MEC pada tahun 2019 dinyatakan tidak lulus dalam uji kompetensi berbicara yang dilaksanakan oleh Lembaga Sertifikasi Uji Kompetensi Bahasa Inggris Maluku.

Pada umumnya dalam proses pelaksanaan kursus dan pelatihan di LKP MEC hanya menggunakan modul, papan tulis dan penghapus yang disertai dengan metode pelatihan convensional yang berpusat pada instruktur, konsekuensinya situasi pembelajaran menjadi sangat membosankan. Kurangnya sarana dan prasarana penunjang juga dirasakan semakin membatasi para peserta kursus dan pelatihan dalam berlatih menggunakan Bahasa Inggris yang mereka pelajari secara komprehensif. Ditambah lagi dengan tidak adanya sumber-sumber bahan ajar yang dapat memberikan input bahasa yang ideal sehingga para peserta kursus terkesan kaku dalam menggunakan Inggris ketika sedang berdialog.

Setiap instruktur dan peserta kursus di LKP MEC harus memiliki wawasan dan pengetahuan teknis mengenai manfaat penggunaan aplikasi multi-media yang terdiri dari audio, teks, dan gambar serta dapat diakses secara bebas melalui jaringan internet seperti podcast dan audiobook. Podcast dan audiobook merupakan aplikasi multi-media yang ideal dalam memberikan input bahasa target kepada setiap pemelajar bahasa[2]. Para ahli meyakini bahwa sebagai produk digital dari World Wide Web, podcast merupakan media yang luar biasa dalam pengajaran Bahasa Inggris[3]. Podcast menggantikan penggunaan $C D, D V D$, Kaset pada setiap laboratorium bahasa[4]. Podcast menyajikan kombinasi audio e-learning, video, dan file teks yang dapat diunduh ke dalam perangkat computer dan gadget untuk digunakan secara off-line maupun on-line [5].

Audiobook juga memiliki berbagai manfaat pedagogis dalam memediasi pemerolehan kemampuan berbahasa bagi setiap pembelajar Bahasa Inggris sebagai bahasa asing. Audiobook membantu para pelajar di Sekolah Menengah Atas dalam belajar Bahasa Inggris[6]. Audiobook mengkombinasikan visual, audio dan teks untuk membantu menumbuhkan pemahaman bahasa yang lebih baik[7]. Audiobook memberikan contoh suara, intonasi, ekspresi, aksen, dialek, dan pengucapan bahasa Inggris yang tepat sehingga dapat menarik minat belajar, serta membantu pelajar auditory dalam memahami setiap materi pembelajaran[8].

Kemampuan berbicara merupakan salah satu kompetensi penting yang harus dimiliki oleh setiap peserta kursus LKP MEC, karena dengan berbicara para peserta kursus dan pelatihan di LKP MEC dapat mengungkapkan ide, gagasan, serta perasaan secara lisan dalam Bahasa Inggris sebagai proses komunikasi kepada orang lain untuk memenuhi kebutuhan masyarakat dan dunia kerja. Oleh karena itu, pelatihan penggunaan podcast dan audiobook untuk meningkatkan kemampuan berbicara peserta kursus di LKP-MEC Namlea, Maluku sangat perlu untuk dilaksanakan, karena dengan pelatihan tersebut para peserta kursus dan pelatihan memperoleh wawasan dan pengetahuan teknis mengenai penggunaan podcast dan audiobook dalam meningkatkan kemampuan berbicara.

\section{METODE}

Survey lapangan, wawancara dengan mitra dan analisis SWOT terlebih dahulu dilakukan dalam pengabdian ini untuk menentukan metode guna menemukan solusi. Kekuatan (strengthening) yang dimiliki oleh LKP MEC adalah visi, misi dan tujuan yang realistis, namun ketidakselarasan antara visi, misi dan tujuan tersebut juga menjadi kelemahan (weaknesses) LKP MEC sebagai suatu lembaga pendidikan non-formal. Dilain pihak, peluang (opportunity) yang dimiliki oleh LKP MEC yakni semakin meningkatnya potensi pengguna lulusan kursus Bahasa Inggris dalam berbagai bidang, yang disertai ancaman (threatening) berupa perkembangan ilmu pengetahuan dan teknologi yang membutuhkan penyesuaian visi, misi, dan tujuan.

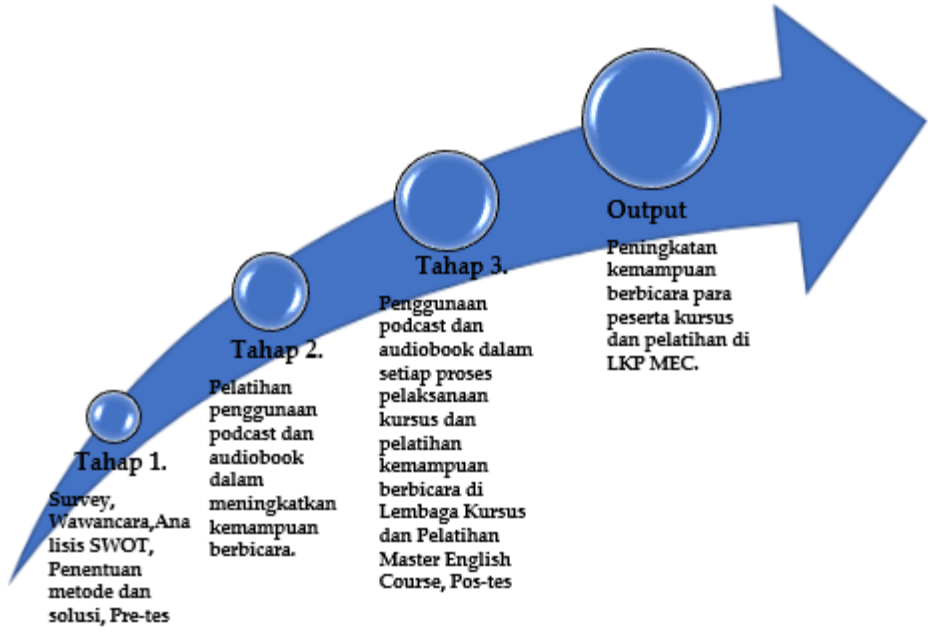

Gambar 1. Metode pelaksanaan pelatihan 
Pre-tes dilakukan untuk mengidentifikasi kemampuan berbicara peserta pada pra pengabdian. Pelatihan diberikan kepada 20 orang peserta kursus yang terdiri dari 6 orang laki-laki, dan 14 orang perempuan. Pelatihan ini dilaksanakan di Lembaga Kursus dan Pelatihan Master English Course, Namlea, Kabupaten Buru, Provinsi Maluku. Kegiatan ini berlangsung selama dua bulan yakni pada bulan september hingga oktober tahun 2020 yang terdiri dari 16 pertemuan pelatihan penggunaan podcast dan audiobook untuk meningkatkan kemampuan berbicara. Materi yang digunakan dalam pelatihan ini adalah materi podcast dan audiobook yang diakses, di download dan di adaptasi dari https://www.bbc.co.uk/learningenglish/, http://eslbits.net/, https://librivox.org/, https://www.digitalbook.io/.

Para peserta dibimbing mengenai tata cara dalam mengakses dan menggunakan podcast atau audiobook melalui media proyektor yang bertujuan untuk memberikan pengetahuan tentang penggunaan media teknologi informasi dan komunikasi untuk meningkatkan kemampuan berbicara. Lebih lanjut, para peserta juga dapat mengakses podcast dan audiobook melalui perangkat/handphone mereka masing-masing mendengarkan percakapan Bahasa Inggris secara mandiri. Materi percakapan pada podcast dan audiobook merupakan materi otentik yang membantu para peserta dalam memperoleh pengetahuan bahasa, karena setiap percakapan atau dialog diucapkan oleh penutur Bahasa Inggris. Setiap peserta meniru cara berbicara, aksen, dialek, dan pengucapan pembicara, disamping itu, mereka mencatat kosakata dan kalimat, dan berlatih berbicara secara berpasangan dengan menggunakan setiap pengetahuan bahasa yang mereka peroleh secara konsisten. Pos-tes dilaksanakan pada akhir pelatihan untuk mengetahui kemampuan peserta setelah diberikan pelatihan.

\section{HASIL DAN PEMBAHASAN}

Hasil tes berbicara melalui pada pra- pengabdian menunjukkan bahwa sebanyak 17 orang atau $85 \%$ dari jumlah peserta yang akan mengikuti pelatihan dinyatakan tidak kompeten dalam penguasaan kemampuan berbicara. Pelatihan berlangsung selama 16 kali pertemuan. Hasil post tes yang dilaksanakan setelah proses pelatihan menunjukkan bahwa sebanyak 15 orang atau $75 \%$ dari jumlah peserta yang telah mengikuti pelatihan dinyatakan kompeten dalam penguasaan kemampuan berbicara. Rata-rata para peserta telah mampu berdialog menggunakan Bahasa Inggris dengan baik dan benar untuk memperkenalkan dan bertukar informasi diri, meminta dan memberi bantuan, melakukan panggilan telepon, mengungkapkan permintaan maaf, membeli dan menjual barang, menjelaskan tentang keluarga, memberikan informasi mengenai suatu negara. menjelaskan pekerjaan seseorang, dan penampilan seseorang, mengekspresikan perasaan, memberikan saran, serta membuat rencana kegiatan. Para peserta menyatakan bahwa pelatihan penggunaan podcast dan audiobook merupakan hal yang menarik dari cara belajar berbicara yang telah dilakukan sebelumnya, seperti menterjemahkan, menulis, menghafal tenses, kata kerja, kata sifat dan kata benda.

Antusiasme yang tinggi ditemukan dalam diri setiap peserta selama rangkaian kegiatan pelatihan penggunaan podcast dan audiobook berlangsung. Pelatihan penggunaan podcast/audiobook juga memotivasi para peserta untuk lebih banyak melakukan latihan berbicara[9]. Sebagai media dan sumber belajar otentik podcast dan audiobook membuka peluang kepada setiap peserta untuk melakukan latihan untuk berbicara menggunakan Bahasa Inggris dari sebelumnya. Materi yang terdapat pada podcast dan audiobook membuat para peserta memperoleh kosakata baru, menghafal bunyi kata yang diucapkan sehingga kompetensi berbicara mereka meningkat[10]. Lebih lanjut, dengan tersedianya file audio percakapan untuk didengarkan, dan transkrip untuk dibaca, serta kegiatan yang telah dirancang khusus untuk berbagai level di internet dan dapat di download untuk disimpan pada handphone maupun computer untuk digunakan secara berulang-ulang merupakan hal baru dan menantang bagi para peserta pelatihan.

Tabel 1. Hasil tes berbicara pra pengabdian dan pasca pengabdian

\begin{tabular}{clcccc}
\hline \multirow{2}{*}{ No } & \multicolumn{1}{c}{ Nama } & Skor Pre-Tes & Predikat & $\begin{array}{c}\text { Skor Post- } \\
\text { Tes }\end{array}$ & Predikat \\
\hline 1 & Akmal Mappa & 20 & Tidak Kompeten & 50 & Tidak Kompeten \\
2 & Anjali Kailul & 25 & Tidak Kompeten & 55 & Tidak Kompeten \\
3 & Avia Tiplen & 20 & Tidak Kompeten & 55 & Tidak Kompeten \\
4 & Darwis Buton & 45 & Tidak Kompeten & 80 & Kompeten \\
5 & Dina Soraya & 35 & Tidak Kompeten & 55 & Tidak Kompeten \\
6 & Fika Puspitasari & 40 & Tidak Kompeten & 75 & Kompeten \\
7 & Firman Suadi & 45 & Tidak Kompeten & 70 & Kompeten \\
8 & Ifti Ayu Souwakil & 45 & Tidak Kompeten & 70 & Kompeten \\
9 & Iskandar Umasugi & 45 & Tidak Kompeten & 70 & Kompeten \\
10 & Karnani Umasugi & 40 & Tidak Kompeten & 75 & Kompeten \\
11 & Natasya Alamudi & 45 & Tidak Kompeten & 75 & Kompeten \\
12 & Nilawati Tuanaya & 70 & Kompeten & 90 & Kompeten
\end{tabular}




\begin{tabular}{lllccc}
13 & Nuraeni Bugis & 40 & Tidak Kompeten & 50 & Tidak Kompeten \\
14 & Rahima Toraha & 45 & Tidak Kompeten & 80 & Kompeten \\
15 & Siska Bugis & 40 & Tidak Kompeten & 75 & Kompeten \\
16 & Sitna Aurelia & 40 & Tidak Kompeten & 70 & Kompeten \\
17 & Suparmin Liya & 45 & Tidak Kompeten & 80 & Kompeten \\
18 & Trisnawati Tarani & 70 & Kompeten & 90 & Kompeten \\
19 & Umiati Tomia & 45 & Tidak Kompeten & 75 & Kompeten \\
20 & Wa Ode Yuti & 75 & Kompeten & 95 & Kompeten \\
\hline
\end{tabular}

Terdapat beberapa mamfaat pelatihan penggunaan podcast dan audiobook diantaranya; dengan pelatihan ini memberikan pengetahuan mengenai penggunaan media yang tepat dalam meningkatkan pengetahuan keterampilan berbahasa (language skills), khususnya kemampuan berbicara yang dapat diterapkan secara aktif dalam kehidupan sehari-hari. Melalui pelatihan penggunaan podcast/audiobook juga menambah wawasan dan pengetahuan sikap berbahasa Inggris yang sesuai dengan konteks dan ragam bahasa karena materi yang konten materi yang ada pada podcast dan audiobook merupakan materi otentik dari penutur Bahasa Inggris yang sesungguhnya.

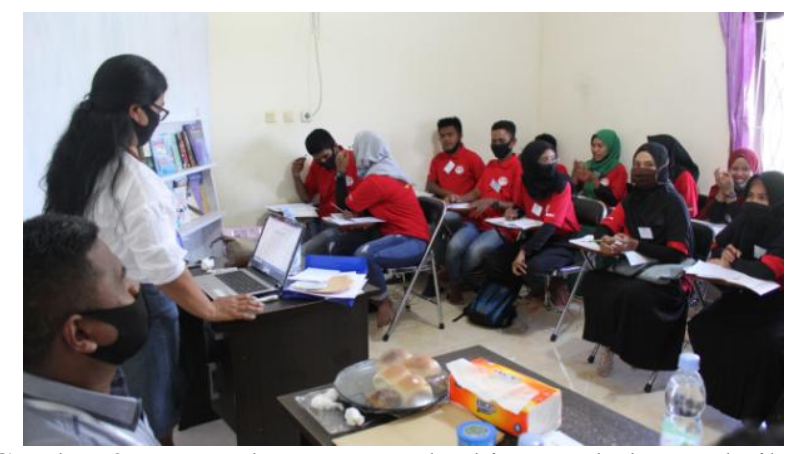

Gambar 2. Pre-tes kemampuan berbicara sebelum pelatihan

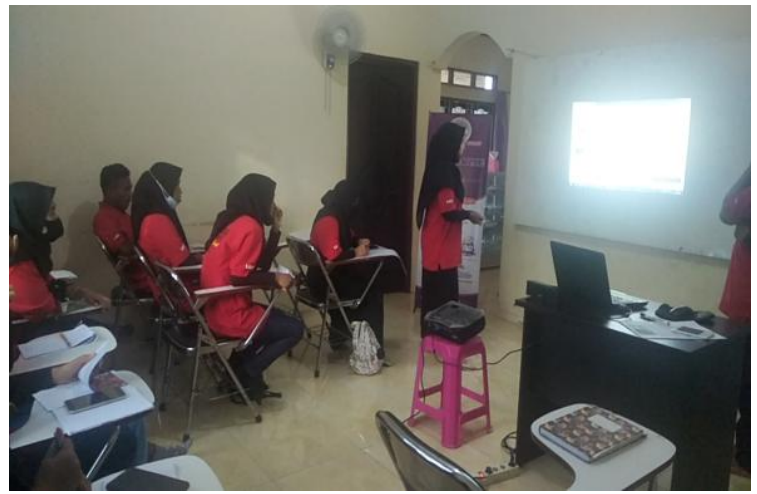

Gambar 3. Pelatihan penggunaan podcast dan audiobook untuk meningkatkan kemampuan berbicara
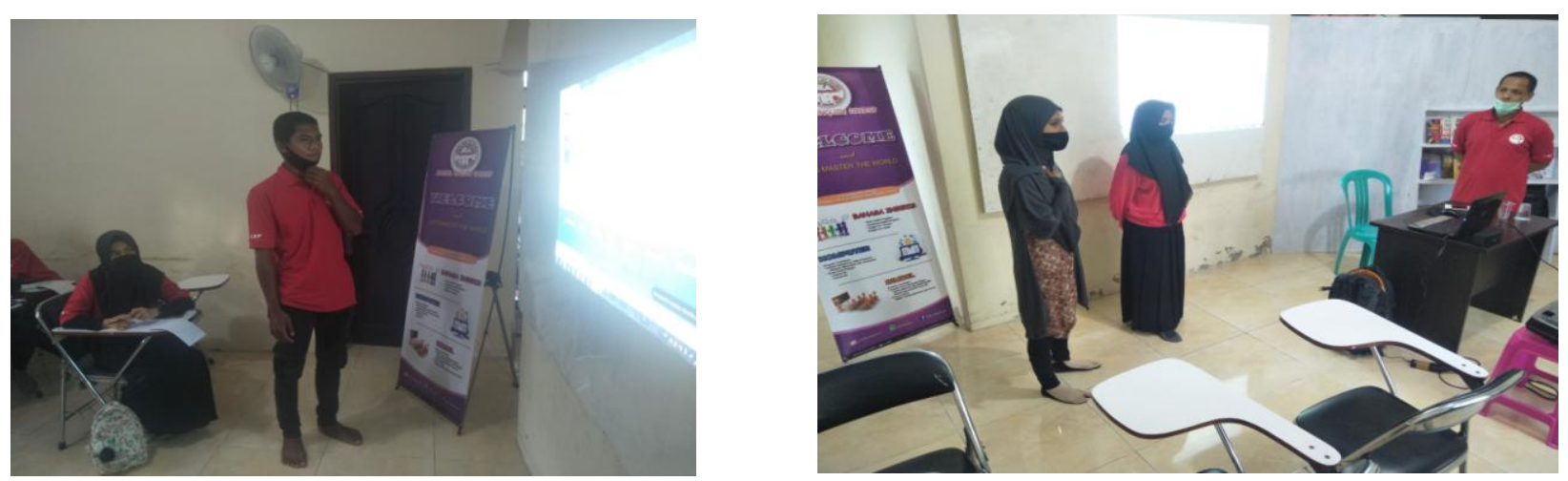

Gambar 4. Praktek berbicara setelah berlatih menggunakan podcast dan audiobook. 


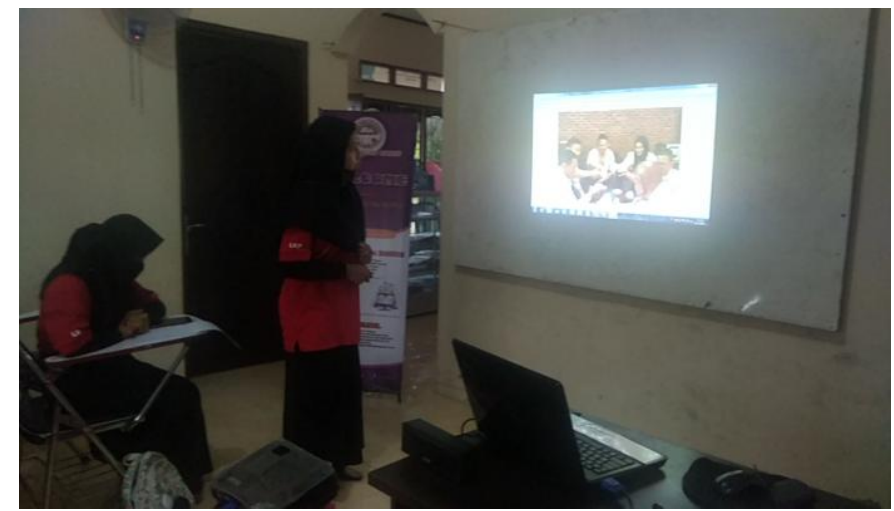

Gambar 5. Post-tes kemampuan berbicara setelah pelatihan

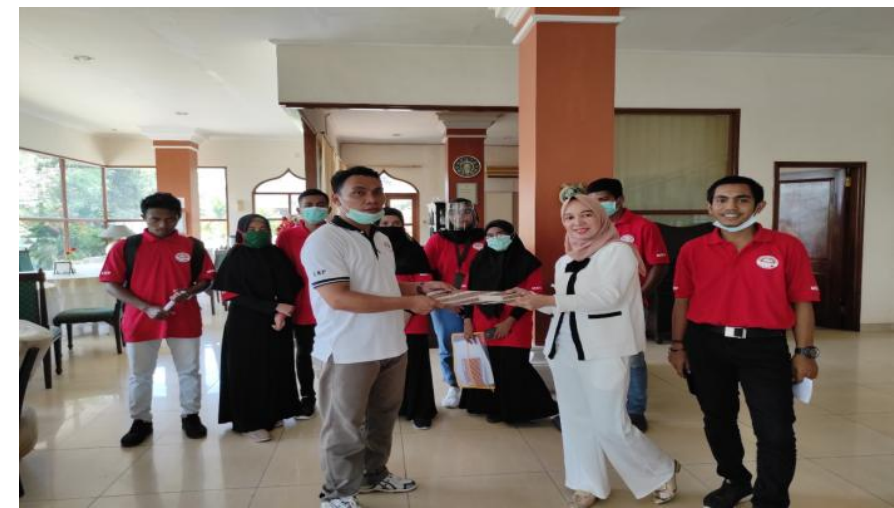

Gambar 6. Magang peserta pelatihan di Hotel Grand Sarah Namlea

\section{KESIMPULAN}

Berdasarkan hasil pelatihan, diketahui bahwa para peserta pelatihan memiliki peningkatan kemampuan berbicara yang signifikan setelah mengikuti pelatihan penggunaan podcast dan audiobook. Pelatihan ini tidak hanya membantu, dan menarik minat namun juga memotivasi para peserta pelatihan di LKP MEC untuk berlatih berbicara dalam Bahasa Inggris dibandingkan dengan cara belajar tradisional yang mereka lakukan sebelum pelatihan berlangsung. Podcast dan audiobook dapat menjadi sebuah solusi dalam mengatasi minimnya kemampuan berbicara para peserta kursus, karena podcast dan audiobook dapat menjadi referensi bahan dan materi ajar yang ideal. Pelatihan penggunaan podcast dan audiobook untuk meningkatkan kemampuan berbicara mengimplikasikan bahwa betapa besar peran alih teknologi informasi dan komunikasi dalam upaya peningkatan kemampuan berbicara dalam Bahasa Inggris sebagai bahasa asing.

\section{DAFTAR PUSTAKA}

[1] 2003 UU RI NO.20, "Undang-Undang Republik Indonesia No 20 Tentang Sistem Pendidikan Nasional," Jakarta Direktorat Pendidik. Menengah Umum, p. 6, 2003, [Online]. Available: http://stpibinainsanmulia.ac.id/wp-content/uploads/2013/04/Lamp_2_UU20-2003-Sisdiknas.doc.

[2] R. Stefancik and E. Stradiotová, "using web 2.0 tool podcast in teaching foreign languages," Adv. Educ., vol. 7, no. 14, pp. 46-55, 2020, doi: 10.20535/2410-8286.198209.

[3] Ebrahim Mohammed Bamanger and Riyadh Abdulrahman Alhassan, "Exploring Podcasting in English as a Foreign Language Learners' Writing Performance,” J. Educ. Pract., vol. 6, no. 11, pp. 63-74, 2015.

[4] A. S. Daniati, A. Mardjohan, and K. S. Piscayanti, "The Use of Podcast to Improve Students' Speaking Competency of Tenth Grade Students of SMA Negeri 1 Amlapura in Academic Year 2015/2016," Ling. Sci., vol. 23, no. 2, p. 34, 2018, doi: 10.23887/ls.v23i2.16073.

[5] A. Rahman, H. Atmowardoyo, and K. Salija, "Podcast Effects on EFL Learners' Listening Comprehension," ELT Worldw. J. English Lang. Teach., vol. 5, no. 2, p. 151, 2018, doi: 
10.26858/eltww.v5i2.7374.

[6] A. Rahman and I. Hajar, "The Effect of Audiobook on Reading Comprehension of the Eleventh Grade Students of SMA Negeri 2 Buru," ELT Worldw. J. English Lang. Teach., vol. 7, no. 2, p. 104, 2020, doi: 10.26858/eltww.v7i2.14931.

[7] M. R. Imawan and A. Ashadi, "Audiobooks for Assisting EFL Students in Reading Independently," $J$. English Lang. Teach. Linguist., vol. 4, no. 1, p. 77, 2019, doi: 10.21462/jeltl.v4i1.198.

[8] E. Marchetti and A. Valente, "Interactivity and multimodality in language learning: the untapped potential of audiobooks," Univers. Access Inf. Soc., vol. 17, no. 2, pp. 257-274, 2018, doi: 10.1007/s10209-0170549-5.

[9] O. R. N. Wulan, "The effect of implementing podcast in enhancing students' speaking achievement in the fully digital era," PEOPLE Int. J. Soc. Sci., vol. 3, no. 3, pp. 1173-1185, 2018, doi: 10.20319/pijss.2018.33.11731185.

[10] A. Bustari, I. A. Samad, and D. Achmad, "The use of podcasts in improving students' speaking skill," JELE (Journal English Lang. Educ., vol. 3, no. 2, p. 97, 2017, doi: 10.26486/jele.v3i2.256. 